\title{
An analysis of the Human Resource practices in the mining industry in Zimbabwe's Midlands Province: A relook at the Resource Based View of managing Human Resources.
}

\author{
Willard Nyamubarwa, Honest Mupani, Clifford Chiduuro \\ Department of Human Resource Management \& Psychology, Great Zimbabwe University, Zimbabwe
}

\begin{abstract}
The mining industry across the globe has always made use of large stocks of labourto achieveorganizational objectives. It is against this background that the study was conducted to determine the HR practices currently being implemented in the mining sector in Zimbabwe. The Results Based View approach to the strategic leadership of organisations was adopted to act as a benchmark against which the current HR practices can be compared with. The research data was gathered through a non-random, convenient sample of HR managers from 8 mining entities in the Midlands Province of Zimbabwe. Convenience sampling was necessitated by the limited finances and time at the disposal of the researcher. However, the relatively large size of the sample would ensure a high degree of generalisability of findings for the mining industry in the Midlands Province in Zimbabwe. The findings of the study revealed that in the mining industry in Zimbabwe, employees are treated as valuable, rare and inimitable resource which they deploy in various ways to achieve organisational objectives. As such the mining companies have come up with innovative methods of managing their human resources which includes providing job security, competitive rewards, and social welfare services amongst other methods. These findings confirm that HR departments in the mining industry in Zimbabwe's Midlands Province are practising the RBV approach to the management of human resources in their organisations and by so doing manage to resource their mining entities efficiently and effectively.
\end{abstract}

Keywords: Human, Mining,Practices, Resource, Zimbabwe

\section{Introduction}

In the current competitive global economic environment in which business is operating in, people and the way they are managed are becoming increasingly important(Luthans \& Hodgett, 1990). This is reflected in the adoption of human resource (HR) practices supporting the creation and development of highly qualified people who are both motivated and committed to their organizations. Thus, the manner in which the company formulates its responsibilities to its employees will affect their performance at work and their loyalty to the company(Luthans \& Hodgett, 1990;Armstrong \& Sweeney, 1994). It therefore means that management in organisations must adopt a philosophy in which employees are seen not as a cost to be reduced but as an asset to be valued(Steen, 2009; Guest, 1997).

This notion that people should be regarded as assets rather than variable costs was originally advanced by (Beer, Spector, Lawrence, Quinn Mills, \& Walton, 1984) and believes that in terms of business strategy, an organization can succeed if it has sustainable competitive advantage and can hold that advantage for a long period of time. Pfeffer, (1994) echoes this school of thought and postulates that achieving success in organisations entails adopting a different approach to employees and labour relations - it means working with employees, not treating them as disposable liabilities but rather treating them as valuable assets and a source of competitive advantage.

Using the Resource-Based View (RBV) of the company, this paper tries to show the strategic importance of deploying the scant human resources in Zimbabwean mining organisations in way that produce the greatest results for as little cost as possible to the organisations. The Resource Based View (RBV) of the firm as discussed by Barney, (1991), Huselid, et al., (1997) and Lepak \& Snell, (1999) amongst many other scholars assumes that sustainable competitive advantage in organisations can be obtained by exploiting the organization's internal strengths and external opportunities whilst minimizing its internal weaknesses and the effects of external threats. The organization's human resources are therefore regarded as a key source of its competitive advantage as they add value, are rare in the marketplace, hard or impossible to imitate and cannot be easily substituted. Thus flexibility in the deployment of human resources has been proffered as a way of sustaining organisational efficiency and effectiveness in the face of a challenging operational environment(Brewster, 2004;Huselid, et al., 1997;Lepak \& Snell, 1999). Such flexible methods of deploying human resources have found favour in different economies across the globeas the case of the Asian Tigers (China, Hon Kong, Thailand, Singapore) where flexible work practices have found firm grounding in many 
organisations(Chow; 1998). Such organisations are said to be adopting the following practices in deploying its workforce

- The freedom to hire and fire their employees

- Subcontractingnon-core activities to other players

○ The use of temporary and casual workers

- Use of a multiskilled workforce

Armstrong, (2006) concurs and points to an organisation's resourcing strategyas one tool HR practitioners can use to deploy and ensure that the organization obtains and retains the people it needs and employ them efficiently to achieve organisational objectives. Similarly, a study by Matangi, (2006)concluded that amongst other practices, HR practitioners in Zimbabwe use flexible deployment of their valued human resources as a survival techninique. This study is an attempt to examine how HR practitioners in the mining industry in Zimbabwe are using their human resources in ways that are mutually beneficial to their organisations and to the employees themselves.

The MidlandsProvinceis a Zimbabweanadministrative province with an area of $49,166 \mathrm{~km}^{2}$ and is home to a number of mines which are dotted along the mineral rich Great Dyke which cut across the province.Be that as it may, the decade long economic challengesin Zimbabwe culminated in world record inflation, poverty and unemployment rates and by the end of 2008, in nearly across all sectors of the economy workers were sent on rotating often unpaid leave and virtually all sectors of the economy had almost been decimated, with capacity utilization levels well below $10 \%$. In the mining sector, nearly all mines were under care and maintenance (Mines, 2012). The inclusive government ushered in February 2009, rapidly implemented a raft of economic stabilization measures designed to end the hyperinflation, achieve macroeconomic stability recovery and growth. Since 2009 mining production has recovered slowly, but has remained hamstrung by a number of challengeswhich includes an acute shortage of skilled labour as many experienced employees migrated to the diaspora during the decade long economic challenges(MMCZ; 2012). This is against to the production oriented nature of the mining industry which calls for the industry to engage a huge labour force in order to maximise returns (Matangi, 2006). Despite these challenges, the mining sector in Zimbabwe is on a growth trajectory and the Zimbabwean government has pinned total economic recovery on the revival of the mining industry (Moyo; 2013). It is against this background that this paper attempts to assess how HR practitioners in the mining sector in Zimbabwe can assist their organisation's growth strategy by deploying their human resources in ways that maximise returns.

\section{Statement of the problem}

The resource-based view of the firm model contends that a firm's ability to perform better than its competitors depends on the unique interplay of human, organizational and physical resources over a period of time. As such, many scholars argue that the employees in organisations that are rare and difficult to replicate must anchor the business processes if a firm is to outperform its rivals and create value. However, the labour market in Zimbabwe in currently characterized by a shortage of skilled and experienced employees needed to meet market demands. This state of affairs has not spared the mining sector which has seen many mines operating on shoe string budgets and therefore failing to attract adequate and experienced labour to meet their objectives. This is compounded by the fact that mines have tended to rely on a huge labour force with a tradition of long term employment (Matangi, 2006). This phenomenon has meant that labour in the mines is hard to replace as a result of their skill base which has been acquired over a long period of time. This uncanny situation has left HR managers in the mining industry in Zimbabwe groping for the best method to deploy the rare, valuable and skilled human resources they have at their disposal for maximum organisational benefit.

\subsection{HRM and the Resource Based View (RBV)}

\section{Literature Review}

An important trend in recent years has been for HR managers to adopt a strategic view of their job and recognize the critical linkages between organizational strategy and HR strategy (Barney, 1991;Sims, 2002). As a result, during the last few years as noted by Delery \& Doty, (1996) the discipline of HRM has shifted from a micro focus on individual HR practices to a debate on how HRM as a more holistic management approach may contribute to the competitive advantage of the organization. The resource-based view of the firm (RBV) was chosen as a conceptual framework for this study because it provides a holistic theoretical bridge between business strategy and HRpractices as noted by Wright, et al., (2001).

According to scholars, (Huselid, et al., 1997; Brewster, 2004), for a long time, the HRM literature was dominated by an 'outside-in' perspective. As a result, external factorssuch as the labour market, the competition within the industry or national culture were argued to influence the use of HR practices in organisations. The RBV opposes this idea and argues that the success of a firm is decisively determined by its specific and unique 
potential coupled with the way it deploys its human resources (Barney, 199; Delery \& Doty, 1996; Huselid, et al., 1997). Thus, internal resources including human resources are regarded as key factors of a firm's performance and success and are an important source of sustainable competitive advantage. (Saá-Pérez \& García-Falcón, 2002; Steen, 2009).

According to Barney, (1991), to obtain competitive advantage a resource must be (1) valuable in the sense of being profitable for the firm, (2) rare among a firm's potential and current competitors, (3)imperfectly imitable, and (4) non-substitutable. It therefore follows that value, inimitability and uniqueness (firm-specificity) are the main characteristics of human resources which leads to competitive advantage. Value refers to the workforce itself where employees with broad qualifications can take up different tasks and "enable a firm to conceive of or implement strategies that improve its efficiency and effectiveness" (Barney, 1991). In other words, a workforce with broad knowledge and skills is more valuable for a firm than that with narrow qualifications.

Uniqueness implies that the workforce has firm-specific capabilities that can best be utilised in the context of a particular firm. Firm specificity makes employees less mobile since a change of the employer would mean a decrease in value for the employee and the firm and is thus less likely to happen. Such an employee is in other words shackled to one employer who values the employee's commitment and deploys the employee efficiently and effectively(Lepak \& Snell, 1999).

Imperfect imitability is the third pillar of sustainable competitive advantage that can be drawn from employees in an organisation. This in other words means that HR processes need to be developed in such a way that they are too complex for competitors to imitate.

It therefore follows that value, uniqueness and inimitability are argued to enhance HRM efficiency(Armstrong \& Sweeney, 1994;Guest, 1997). In a Zimbabwean context, this means that HRM practices with these three characteristics have a positive impact on the quantity and quality of employees, their deployment in the organisation and the attrition rate. The mining industry in Zimbabwe would harness the rewards associated with the committed human resources they have at their disposal by deploying them in ways that maximise returns on the firm guarantee that the employees are committed to the organisations. This high-commitment model of responsiveness toward employees is similar to Guest's (1987) well-known 'soft' model of HRM, which sees employees as valued assets because of their commitment, adaptability and high quality (of skills, performance and so on). The watchwords in such a model are investment and value added, rather than exploitation and cost minimization (Legge, 1998)

\subsection{Vertical integration and HR strategy choice}

Human resources management needs to be closely integrated with managerial planning and decision making in organisations (Sims, 2002). A closer integration between top management's goals and HRM practices helps to elicit and reward the types of behaviour necessary for achieving an organization's strategy. As Bratton \& Gold, (2003) notes if an organization is planning to become known for its high-quality products, HRM staff should design HR practices that emphasize quality in order to support this competitive strategy. In other words, the HRM planning process should involve forecasting HR needs and developing programs to ensure that the right numbers and types of individuals are available at the right time and place. (Bratton \& Gold, 2003; Guest, 1987; Steen, 2009). As such, mining companies in the Midlands Province in Zimbabwe need to keep their HR strategic plans in line with the overall organisational strategies.

\subsection{High-involvement management}

The concept employee involvement in the managements of organisations is yet a key factor of the Resource Based View of managing organisations (Armstrong, 2005;Boxall, 1996). This approach involves treating employees as partners in the management and leadership of organisationswhose interests are respected by top management. The aim is tocreate a climate in which a continuing dialogue between managers and themembers of their teams takes place in order to define expectations and shareinformation on the organization's mission, values and objectives (Armstrong, 2005;Boxall, 1996;Guest, 1987). This establishes a common understanding of what isto be achieved and a framework formanaging and developing people to ensure that it willbe achieved. MacDuffie, (1995)and Osterman, (1994), points to focused on the use of formal work teams, employee involvement groups,job rotation,quality circles, product-related suggestions made and implemented by employees, the use of job rotation within and across teams, and carrying out quality tasks as examples of employee involvement in the management of organisations.

\subsection{Employee resourcing and organisational success}

According to Bratton \& Gold, (2003), personnel recruitment can be defined as the process ofgenerating a pool of people capable of applying for employment to an organization. Employers caneither be recruited internally within a firm or from the external labour market. When expandingon a grand scale and in a short time with limited resources, firms must also attract qualified candidates from the external labour market. Since the number 
of qualified and experienced people in Zimbabwe is very limited, firms have to find innovative ways of personnel marketing to enlarge this pool of potential employees e.g. byfocusing on a wider geographical area or applying a wider spectrum of HR practices (Armstrong \& Sweeney, 1994;Arthur, 1994).

\subsection{Employee development and training}

Likewise, personnel development is an essential ingredient in creating a unique and valuable workforce in organisations (Armstrong, 2006; Steen, 2009). Companies in Zimbabwe which are facing anincreased demand for skilled and experienced employees, may not expect newly recruited people to be able to take up jobs without intense company-level training.From a RBV perspective, particularly team-oriented training (value), firmspecific training (uniqueness), and in-house training (inimitability) can enhance the spectrum of employee deployment in the organisation. This view agrees with de la Cruz Déniz-Déniz \& De Saá-Pérez, (2003) whoargues that it coincides with the dictates of the unitarist approach to labour relations, which seeks to integrate employer and employee interests, while at the same time maximizing employee involvement in and commitment to the organization. This again widens the spectrum of employee deployment in organisations. As Boxall, (1996) points out, 'by hiring and developing talented staff and synergising their contributions within the resource bundle of the firm, HRM may lay the basis for sustained competitive advantage'.

\subsection{Human resources as human capital in organisations}

Wright, et al., (1994) distinguished between the firm's human resources (i.e., the human capital pool) and HR practices (those HR tools used to manage the human capital pool). In applying the concepts of value, rareness, inimitability, and substitutability, they argued the HR practices could not form the basis for sustainable competitive advantage since any individual HR practice could be easily copied by competitors. Rather, they proposed that the human capital pool (a highly skilled and highly motivated workforce) has greater potential to constitute a source of sustainable competitive advantage. (Wright, Dunford, \& Snell, Human resources and the resource based view of the firm, 2001). These scholars noted that to constitute a source of competitive advantage, the human capital pool must have both high levels of skill and a willingness (i.e., motivation) to exhibit productive behaviour.

Thus, for the purposes of this article, an HR system is defined as 'an organizational capability which involves the strategic integration of the set of HR activities, functions and processes: selection, training, appraisal, promotion and compensation, carried out to attract, develop and maintain the strategic HR that allow the firm to achieve its goals' (Delery \& Doty, 1996). According to Barney and Wright (1998), the underlying assumption of Results Based View approach to HRM is that in order for firms to achieve sustained competitive advantage, there is a need for a firm to have unique resources and capabilities. Managers need, therefore, to discover and exploit the valuable, rare and costly-to-imitate resources in their organisation. In short, RBV has its grounding in the following basic tenets:

$\bigcirc$ the firm is a bundle of capabilities and competencies, both human and physical;

- competitive advantage of each firm is tied to how these resources are organised;

- management of human resources is central to the organisation of competencies and thus the competitiveness of the enterprise

Although HR management is not a sufficient condition in itself for competitive advantage, it can still play a necessary role in stimulating change and 'start a process that results in a more extensive tapping of the organization's hidden reservoir, its human resources(Barney, 1991; Huselid, et al., 1997;Luthans \& Hodgett, 1990).

\section{Research Methodology}

The researcher adopted the qualitative research methodology. The aim of qualitative researchers is to gather an in-depth comprehension of human behaviour as well as the reasons that govern such behaviours. The qualitative inquiry allows social science researchers to use smaller but focused samples yet generalise the findings to wider population. Qualitative research methodology was chosen also on the basis that it allows research respondents to narrate their unique experiences in as far the HR practices prevailing in the mining industry in Zimbabwe.

Convenient sampling was used in this study. Convenience sampling is a sampling procedure whereby the researcher makes use of participants that are readily available to participate in a study (Coolican 2009).

The interview method was seen as the best since it allowed respondents to express themselves freely without being limited in their responses. In addition, an interview schedule also gave the researcher an opportunity to probe and follow up on questions that were not clearly addressed by the participants as well as introduce some new questions which would have emerged during an interview session. The interview schedule was pre-tested in four interviews with HR managers. Recommendations and suggestions were incorporated and the former interview schedule was adjusted accordingly. 
The research data was gathered through a non-random, convenient sample of HR managers from 8 of the 12 mining entities in the Midlands Province of Zimbabwe from a list of mines supplied by the Chamber of Mines of Zimbabwe. Convenience sampling was necessitated by the limited finances and time at the disposal of the research. However, the relatively large size of the sample would ensure a high degree of generalisability of findings for the mining industry in the Midlands Province in Zimbabwe. Using an interview guide to ensure consistency in the interview content, the researcher however took the opportunity where necessary to probe the respondents for clarification on certain responses. In order to triangulate the research and produce more reliable and valid findings, the researcher decided to create a questionnaire and administer it to randomly selected employees on the mines. Given the nature of the topic, which entailed soliciting attitudes and opinions on a social phenomenon, a qualitative, interpretivist approach was most appropriate

\subsection{Measures}

The measures were developed on the basis of previous empirical studies in the field of HRM.In this research, the researcher adopted those HR practices most consistent with prior theoretical and empirical work (Arthur, 1994; Dyer and Reeves, 1995; Huselid, 1995; MacDufee, 1995; Becker and Gerhart, 1996; Koch and McGrath, 1996). These practices included aspects like personnel selection, performance appraisal, unique rewards, teamwork and others.

\section{Findings}

The aim of the study was to explore the HR practices in the mining industry in Zimbabwe's Midlands Province.The study drew interesting findings on the HR practices as they relate to the RBV approach to the management of human resources. All the respondents indicated that mines are generally labour intensive organisations and they therefore they don't have an option but to treat their employees as a key asset in tandem with the dictates of the RBV approach to managing people in organisations.

\subsection{Employee training and career planning}

All the respondents indicated that they are taking care of the employees at their disposal by ensuring that the employees are continuously trained to keep them "valuable" to the organisation. As such the majority of the respondents $90 \%$ indicated that they have fully staffed and autonomous training departments. This observation is in tandem withArmstrong, (2005),Boxall, (1996) and de la Cruz Déniz-Déniz \& De Saá-Pérez, (2003)who observed that firm investments by organisations in training will have a positive impact on the extent to which the firm succeeds in developing the skills/knowledge of its employees and at the same time treat them as a rare, valuable and inimitable asset.Huselid, et al. (1997) and Fey, et al. (2000) takes the argument further and assert that firms with superior training programmes tend to experience lower staff turnover and higher employee commitment than companies that neglect staff development.

\subsection{Flexible resourcing}

The study revealed that the HR functions in the mines under review practiced flexible deployment of labour as suggested by. All the respondents concurred that the shortage and expense of mine labour has compelled them to use flexibility in the deployment of the human resources at their disposal. This is done by amongst other things using contract labour especially for short term and high value jobs like engineering projects.

Another common method identified is the creation of autonomous teams. This is in tandem with a similar research carried out by Matangi (2006) in Zimbabwe who claimed that teams and teamwork is the end and all of mining. She concluded in the study that is inevitable not to work in team in the mining industry. The observation is also backed up by a number of scholars (Arthur, 1994;MacDuffiee, 1995; Pfeffer, 1995) who agree that teamwork enhances employee commitment to the organization.

According to the findings of this study, multiskilling is also used to flexibly deploy human resources in the mining sector in Zimbabwe. Multi-skilling according to Armstrong (2006) creates a pool of workers who possess and can apply a number of skill in the organisation.In this study the pool of multiskilled employees identified possessed skills that allowed to be deployed as drivers, operate drilling machines, blasters, miners and other supervisory roles. This is despite the fact that the study revealed that trade unions were opposed to multiskilling. According to another mine manager: 'Unions hate multi-skilling, they call it "multi-killing". In some sites, the dislike of this work organisation method goes beyond just name calling to actual resistance. As observed by one HR manager: ' . . . multi-skilling has beenconsidered, but it has met with resistance from unions'. However, despite the hostility towards a practice viewed as a threat to jobs some sites continue to see the need to use it, as a much-needed responsive mechanism to the challenging economic environment the mines are operating in. 


\subsection{Rewards systems}

Most studies have included performance-based compensation as one of the high-performance HRM practices that HR practitioners can apply in effectively managing their human resources (Arthur, 1994; Delery and Doty, 1996;Huselid, 1995). As Fey, et al. (2000) observes, based on Vroom's expectancy theory, if a company provides rewards desired by the employee in question, this employee is morelikely to perform in a way that will bring him/her the reward. As such the respondents indicated that the mining entities are using high rewards contingent on performance as a tool to attract and retain highly skilled employees. A range of reward systems were proffered and include the following.

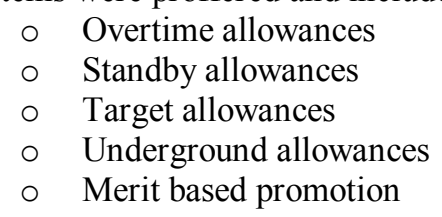

\subsection{Job security}

Companies that provide their employees with job security signal a longstanding commitment to their workforce (Fey, Björkman, \& Pavlovskaya, 2000). An employer that signalsthrough words and deed that its employees are dispensable is not likely to generatemuch loyalty, commitment, or willingness to expend extra effort for the organization's benefit'(Pfeffer, 1994). In addition the concept of job security is also prescribed by other scholars as a technique of showing how an employer treats his employees (rare, value and inimitable). Armstrong (2005), Bratton \& Gold (2003) and Steen (2009) agree and argue that not providing employees with job security is tantamount to breaching the psychological contract that seemily exist between employers and their employees. The study reveled that the provision of job security was one HR practice that HR functions in Zimbabwes mining sector are using today. At one particular site the researcher witnessed a number of emplyees who have been working for that particular employer since the 1970's a sure indication of job security.

\subsection{Internal promotion}

Another importatnt aspect of job security uncovered by the study is the use of internal promotion as a method of showing value to employees in the mining sector in Zimbabwe. The study revealed that the mining sector in Zimbabwes Midlands Province makes use of internal promotion. As such 70\% of the respondents indicated that as HR practitioners they had clear policies on creating career ladders for employees at all levels in the organisation. This finding concurs with Guest(1997) who argues that the availability of career possibilities within organisations tends topromote a higher degree of organizational commitment among employees who perceive clear career possibilities with the firm. Additionally, an emphasis on internalpromotion is likely to provide a sense of fairness and justice among the employees whonote that organizational tenure is valued in the company (Pfeffer, 1995). Therefore,promotion from within as was discovered in the study is likely to be associated with the employees having a sense of worthiness (value), high motivation and low employee turnover(Fey, Björkman, \& Pavlovskaya, 2000).

\subsection{Dispute resolution and employee welfare systems}

According to Gaidzanwa (1991) in mining communities the families of miners interact closely with the employers of their husbands and fathers. As such, their housing, schooling, leisure activities and incomes, indeed, their whole lives aredetermined by the mining company and has the potential of generating friction. The existence of a well-functioning disputeresolution system may help alleviate situations of perceived injustice or conflicts inmining communities (Morrison and Robinson, 1997). The study revealed that $90 \%$ of the respondent's mines have fully functional"Industrial Relations" and "Welfare" departments whose role is to maintainsynergies between employees and their families resident on the mines. This observation was supported byMines (2012) whose report indicated that though there was a wage dispute between the Zimbabwe Chamber of Mines as a body representing the miners and the employees represented by the Associated Mine Workers Union of Zimbabwe (AMWUZ), there is now a lull in industrial relations in the mining sector in Zimbabwe a clear indication of the mutuality and unitarismbetween employees and their employers in the mining industry in Zimbabwe. This lull in industrial relations and the resultant mutualityvalidates the outcome of the RBV approach of managing employees as research over the years has proven (Brewster, 2004; Delery \& Doty, 1996; Fey, et al., 2000; Huselid, et al., 1997)

\subsection{Safe and Healthy Work Environment}

Mining has always been a risky occupation. This observation is supported by (Gaidzanwa, 1991) who claims that the safety records of Zimbabwean mines is deplorable especially the small scale mines. An 
important source of workplace change has been the desire to promote a safer and healthier work environment. Legal, social, and political pressures on organizations ensure that the health andsafety of their employees continue to have a great impact on HRM practices. The study revealed that HR practitioners are concerned with the health and safety of their otherwise valuable employees. This concern manifests itself in a number of ways including proving on-going safety training, providing safety clothing and in some instances providing free health care facilities at the workplace.

\section{Conclusion}

In conclusion, RBV can be applied to explain how management organise human resources inorder to cope with the threat to the efficient and effective use of labour in organisations. Therefore, in the turbulent economic environment in which mines are operating in Zimbabwe, there is a need for firms to continually acquire, develop and update theirresources and capabilities in order to remain both efficient and competitive. Given its focuson the resources of the firm RBV can be adopted to help explain HR manager's responses tothe challenges in the mining industry today. These challenges include coping with the need to deploy a mean efficient and cost effective labour force in the light of a skills shortage, tough economic conditions and the desire for large labour forces by mining entities.

RBV was able to shed light on efforts made bymining sites to fully utilise existing resources in their effort to deploy the human resources effectively and efficiently. Thus thedeployment of resources as used in RBV literature can be paralleled to managementefforts, in the mining sites, to manage work organisation in a way that will get the most outof workers in the workplace using the most cost efficient means possible. The HR managers in the study are seen as having a number of ways of organising miners in order toget the most out of them. Thus, based on the assumption that the modern type firm seeksoptimum efficiency, work organisation is a concept that can be manipulated in differentways by management in order to renew or revitalise productive capacity.

\section{Limitations}

Like all research, this study has some limitations which future research can build on. The study used a convenience sample drawn from a section of the Zimbabwean mining sector and hence, it may not be appropriate to generalize findings based on a convenience sample beyond the firms in the sample. Future researchers may have to adopt multiple methods foroperationalizing the RBV approach to HR systems such as factor analysis, cluster analysis, andreliability analysis.

Another weakness ofthis study is that all data are collected from a single source(HR Managers). Future studies are urged to have different sources (employees, trade unions, mine managers etc) in order to evaluate HRM practices in the mining sector.

\section{References}

[1]. Armstrong, M., 2005. Strategic human resource management : a guide to action. 3rd ed. London: Kogan Page.

[2]. Armstrong, M., 2006. Human Resources Management. London: Kogan Page.

[3]. Armstrong, R. \& Sweeney, J., 1994. Industry type, culture, mode of entry and perceptions of international marketings ethics problems: A cross-cultural comparison. Journal of business ethics, Volume 13, pp. 775-785.

[4]. Arthur, J., 1994. Effects of Human Resource Systems on Manufacturing Perfomamnce and Turnover. Academy of Management Journal, Volume 37, pp. 670-87.

[5]. Barney, J., 1991. Firm Resources and Sustained Competitive Advantage. Journal of Management, 17(1), pp. 99-120.

[6]. Boxall, P. F., 1996. The Strategic HRM debate and the resource-based view of the firm.. Human Resource Management Journal, $6(3)$, p. $59-75$.

[7]. Bratton, J. \& Gold, J., 2003. Human Resource Management. Theory and Practice. Basingstoke: Palgrave MacMillan..

[8]. Brewster, C., 2004. European perspectives on human resource management. Human Resource Review, 14(4), pp. 365-382.

[9]. Chikoko, L. \& Samu, A., 2009. Zimbabwe industrial equity index determinants in the multiple currency regime of 2009. The Dyke: Journal of Midlands State University, 6(3), pp. 1-15.

[10]. Chow, I., 1998. The impact of workforce flexibility in Hong Kong. International Journal of Human Resource Management, 9(3), pp. 494-505.

[11]. de la Cruz Déniz-Déniz, M. \& De Saá-Pérez, P., 2003. A Resource-Based View of Corporate Responsiveness Toward Employees. Organization Studies, 20(2), p. 299-319.

[12]. Delery, J. \& Doty, D., 1996. Modes of Theorizing in Strategic Human Resource Management: Tests of Universalistic, Contingency, and Configurational Performance Predictions. Academy of Management Journal, Volume 39, pp. 802-35.

[13]. Fey, C. F., Björkman, I. \& Pavlovskaya, A., 2000. The effect of human human resource management practices on firm performance in Russia,. The International Journal of Human Resource, 11(1), pp. 1-18.

[14]. Gaidzanwa, R., 1991. Labour relations in a mining enterprise established after independence. Zambezia, 17(1), pp. 49-67.

[15]. Guest, D., 1987. Human resource management and industrial relations. Journal of Management Studies, 24(5), pp. 503-521.

[16]. Guest, D., 1997. Human resource management and performance: A review and research agenda. International Journal of Human Resource Management, Volume 8, pp. 263-276.

[17]. Huselid, M. A., Jackson, S. E. \& Schuler, R. S., 1997. Technical and strategic human resources management as effectiveness as determinates of firm performance. Academy of Management Journal, 40(1), pp. 171-189.

[18]. Legge, K., 1998. Is HRM ethical? Can HRM be ethical?. In: M. Parker, ed. Ethics and organisations. London: Sage.

[19]. Lepak, D., Liao, H., Chung, Y. \& Harden, E. E., 2006. A conceptual review of HRM systems in strategic human resource management research. In: J. Marticchio, ed. Research in Personell. s.1.:Elsevier, pp. 217-271. 
[20]. Lepak, D. P. \& Snell, S. A., 1999. The Human Resource Architecture: Toward a Theory of Human Capital Allocation and Development. Academy of Management Review, 24(1), pp. 31-48.

[21]. Luthans, F. \& Hodgett, R., 1990. Social issues in business: Strategic and public policy perspectives. 6th ed. New York: Macmillan.

[22]. MacDuffie, J. P., 1995. Human resource bundles and manufacturing performance: Organizational logic and flexible production systems in the world auto industry. Industrial and Labour Relations Review, Volume 48, p. 197-221.

[23]. Matangi, C., 2006. Skills under threat: The case of HIV/AIDS in the Mining industry in Zimbabwe. Journal of International Development, Volume 18, p. 599-628.

[24]. Mines, Z. C. o., 2012. [Online].

[25]. Morrinson, E. \& Robinson, S., 1997. When Employees Feel Betrayed: A Model of How Psychological Contract Violations Develop. Academy of Management Review, Volume 22, pp. 226-56.

[26]. Moyo, R., 2013. Mining sector to bring in US\$6bln: MMCZ. [Online] Available at: http://www.newzimbabwe.com/business-11654Mining\%20sector\%20to\%20bring\%20in\%20US\$6bln\%20MMCZ/business.aspx [Accessed 4 August 2013].

[27]. Osterman, P., 1994. How common is workplace transformation and who adopts it?. Industrial and Labour Relations Review, Volume 47, pp. 173-188.

[28]. Pfeffer, J., 1994. Competitive advatage through people. California management review, Volume 36, pp. 9-29.

[29]. Saá-Pérez, P. D. \& García-Falcón, J., 2002. A Resource-Based View of Human Resource Management and Organizational Capabilities Development',. International Journal of Human Resource Management, 13(1), pp. 123-140.

[30]. Sims, R., 2002. Effective Human Resources Management. Westport, Connecticut: Quorum Books.

[31]. Steen, S., 2009. Human Resource Management. Toronto: Mc-Graw Hill.

[32]. Wright, P., Dunford, B. \& Snell, S., 2001. Human resources and the resource based view of the firm. Journal of Management, Volume 27, p. 701-721.

[33]. Wright, P., Dunford, B. \& Snell, S., 2001. Human Resources and the Resource-Based View of the firm. Journal of Management, 27(6), pp. 701-721.

[34]. Wright, P., McMahan, G. \& McWilliams, A., 1994. Human resources and sustained competitive advatage: A resource based perspectives. International Journal of Human Resource Management, 5(2), pp. 301-326. 